\title{
実暴露試験に基づくニッケル系高耐候性鋼の 長期腐食量予测*
}

\author{
鹿毛 勇 ${ }^{* *}$, 塩谷和彦 ${ }^{* *}$, 竹村誠洋 ${ }^{* *}$, 小森 務 ${ }^{* *}$, 古田彰彦 ${ }^{* *}$, 京野一章** \\ ** JFE スチール株式会社 スチール研究所 \\ ***JFE スチール株式会社 スチール研究所 (現 : 独立行政法人 物質・材料研究機構)
}

\section{Estimation of Corrosion Loss for $\mathrm{N} \mathrm{i-added} \mathrm{High} \mathrm{Corrosion} \mathrm{Resistant}$ Weathering Steel based on Field Exposure Test*}

\author{
Isamu Kage**, Kazuhiko Shiotani ${ }^{* *}$, M asahiro Takemura***, \\ Tsutomu Komori ${ }^{* *}$, Akihiko Furuta** and Kazuaki Kyono** \\ ** JFE Steel Corporation Steel Research Laboratory \\ *** JFE Steel Corporation Steel Research Laboratory (Presently The National Institute for M aterials Science)
}

\begin{abstract}
As for the weathering steel, it is important to judge whether to suit the environment when applying to the structure. The authors presented the expression that allowed the environmental factor and amount of corrosion loss based on the results of the atmospheric exposure tests for weathering steel (JIS-SM A) and the Ni-added high corrosion resistant weathering steels in nationwide various places.

In the present paper, the method to estimate the corrosion loss that had been proposed up to now was arranged. The characteristics of a domestic environment were clarified based on the results of the atmospheric exposure tests. In addition to the corrosion examination results of these steels in the laboratory, the corrosion estimation curve was proposed. As a result, the corrosion resistance of the weathering steel was in good agreement with the corrosion loss estimated with the past knowledge. The $\mathrm{Ni}$-added high corrosion resistant weathering steel had the possibility to show higher corrosion resistance against salinity than the result estimated with weathering alloy index V-value that had been proposed up to now. In addition, the amount of corrosion loss can be decreased by giving the structure receiving the rainfall and the rust stabilization assistance processing.
\end{abstract}

Keywords : atmosperic corrosion, weathering steel, estimation of corrosion loss, steel bridge, temperature, relative humidity, air-borne salinity, exposure test

1. 緒

言

耐候性鋼は，表層に生じたさびの保護性により腐食の 進行を低下せしめる鋼材である . 耐候性鋼は, 無塗装で 構造物に使用することで, 維持管理にかかる塗装費用を 中心としたライフサイクルコストを低減する特長を有す る. 耐候性鋼の腐食による板厚減少量は, 構造強度上の 問題を生じない範囲であることが必要である．したがっ て, 他の環境とを遮断する防食方法とは異なり, 適用に あたっては環境に適合するかどうかの判断を必要とする．

環境に対する適用指針として, 現在JIS G 3114 で規定 されている耐候性鋼（以下ではJIS-SMA と略す）は， 1982 年から実施された独立行政法人土木研究所，(社）鋼 材俱楽部，(社）日本橋梁建設協会の三者による全国にお よぶ耐候性鋼の暴露試験 ${ }^{1)}$ 結果（以下では三者共研と呼 ぶ）をまとめ, 飛来塩分量が $0.05 \mathrm{mg} \mathrm{NaCl} / \mathrm{dm}^{2} /$ day（以 下 $\mathrm{mdd}$ と略す）以下の地域として適用の目安を定めてい る. 1998 年，宇佐見 ${ }^{2)}$ らにってより高い塩分環境に強 い耐候性鋼材としてニッケル系高耐候性鋼が開発され た. 2003 年, 紀平ら ${ }^{3)-5) ~}$ は, 架設環境での耐候性鋼の適 用性を簡便に判定するために, 当該地の環境因子のみか

第 51 回材料と環境討論会 (名古屋, 2004 年) で一部発表

厂 210-0855 川崎市川崎区南渡田町 1-1 (1-1, M inamiwataridacho, Kawasaki-ku, Kawasaki, 210-0855 Japan)
ら耐候性鋼の腐食量を推定する式を構築し, 弚の環境適 用性判断手法を体系化した .

しかしながら，ニッケル系高耐候性鋼は，開発からの 歴史が浅いため, 国内各地での暴露試験データに基づい た検証は必ずしも多くはない．著者らは1998 年から JISSM A ならびに 2 種類のニッケル系高耐候性鋼について全 国各地の暴露試験を行い，腐食挙動を解析してきた6). 本論文では, 最初にこれまで提案されてきた腐食予測方 法を整理し，暴露試験の結果に基づいて，飛来塩分を代 表とする国内環境に対する特性変化を明らかにし, 次に これらの鋼材について一部実験室で行った腐食試験結果 を加え, 腐食予測曲線を立案した.さらに, 腐食におよ ぼす降雨やさび安定化補助処理の影響を考察したので報 告する .

\section{2. 大気中における耐候性鋼の腐食予測式 における従来の知見}

耐候性鋼の腐食の抑制効果を経過年数の関数として表 すには 堀川らの式7)を変形した (1) 式がよく一致する .
$Y=A X^{B}$
$(\mathrm{B} \leqq 1)$
$Y$ : 片側平均板厚減少量 $(\mathrm{mm}), X$ : 時間（年）, A， $B:$ 係数.

従来, 係数 A と B は, 主に暴露試験結果に基づく回帰 によって決定され, 弚の場における将来予測に用いられ てきた．しかし，回帰による予測は, 腐食データのない 
地点における腐食量を予測することはできない，乥こで 各環境因子を用いて，係数 A，B を表すことが試みられて きた ${ }^{8)}$.

1986 年に建設省総合技術開発プロジェクトに基づき発 行された（財）国土開発技術研究センター編「鉄骨造建築 物の耐久性向上技術」) では, 表面無処理鋼材の地域環境 別設計用劣化係数の記述中で，「鋼材の腐食は湿式腐食 が中心で, 土中, 水中, 密閉構造の内部を除いて, 酸素 量は, ほぼ一定と仮定すると, 水分の劣化現象への影響 は鋼材への濡れ時間で評価できる.」とし，外部からの 腐食劣化への影響を(2) 式に示すように濡れ時間に比例 することが提案されている .

劣化外力 $=($ 促進係数 $) \times($ 温度関数 $) \times($ 濡机時間 $)$

ここで(2)式の各々の項は, 環境をランク付けした指標 で表したもので, 実環境の数値を用いて腐食量を計算す るものではなかった .しかし(2)式には，

1）さび/鋼界面に水（酸素, 電解質) の存在下で腐食 は生じる．すなわち濡れ時間に比例する．

2）腐食速度は電気化学反応速度論に従う.すなわち 温度に依存する。

という電気化学に基本を置いた考え方が内在し，これは 本予測方法への応用が可能である.

1993 年に独立行政法人土木研究所は, 三者共研を詳細 に解析 ${ }^{10)} し$, 係数 A に対して促進因子として, 具体的に 数値として取り込む(3)式を提案している.

$$
\begin{aligned}
& \mathrm{A}=\mathrm{kC} \gamma(\text { ただし }, \mathrm{C} \leqq 0.1 \text { のとき }, \gamma=0.487) \\
& \mathrm{B}=0.73(\text { 一定 }) \\
& \mathrm{C}: \text { 飛来塩分量 }(\mathrm{mdd})
\end{aligned}
$$

しかし (3) 式で全国各地の耐候性鋼の腐食量を予測する には ,

a） 係数 A には飛来塩分以外の促進因子が考慮されて いない

b）係数 Bには環境によって依存する特性が取り込ま れていない

といった課題があった .

1997 年,「新発電システムの標準化に関する調査研究」 ${ }^{11)}$

では, 暴露試験と同時に飛来塩分以外の温度, 硫黄酸化 物, 濡れ時間といった環境因子を測定し, 腐食量との相 関を解析し，各々の相関を求めている.

2003 年, 紀平ら ${ }^{4), 5}$ は環境の腐食性指標 Zを(4)式で表 ᄂ,

$$
\begin{aligned}
\mathrm{Z}= & \alpha \square \mathrm{TOW} \square \exp (-\kappa \mathrm{W}) \square(\mathrm{C}+\delta \square \mathrm{S}) / \\
& (1+\varepsilon \square \mathrm{C} \square \mathrm{S}) \square \exp \left\{-\mathrm{E}_{\mathrm{a}}(\mathrm{RT})\right\}
\end{aligned}
$$

TOW : 濡れ時間 (Kucera ${ }^{12}$ ) らの濡れ関数)，W : 風 速効果 $(\mathrm{m} / \mathrm{s}), \mathrm{C}$ : 飛来塩分量 $(\mathrm{mdd}), \mathrm{S}$ : 硫黄酸 化物量 $(\mathrm{mdd}), \mathrm{T}$ : 気温 $(\mathrm{K}), \mathrm{E}_{\mathrm{a}}$ : 腐食反応の活性 化エネルギー $(\mathrm{kJ} / \mathrm{mol} \mathrm{K} \mathrm{K}), \mathrm{R}:$ 気体定数 $(\mathrm{J} / \mathrm{mol} \mathrm{K} \mathrm{K})$, $\kappa, \delta, \varepsilon:$ 定数, $\alpha:$ 係数.
気象データを用いて算出した Z と A の関係を三者共研の データの回帰によって求め,一方，Bについては, 環境 に依存するA の関数として表すことにより，気象データ のみから国内各地の腐食量を予測する技術を初めて提案 した。

さらに, ニッケル系高耐候性鋼について, 弚の合金成 分を耐候性鋼指標として各種鋼材の暴露試験などから各 種ニッケル系高耐候性鋼と SM A の係数 A, B の比を求め,

$$
\begin{aligned}
\mathrm{A} / \mathrm{A}_{\text {SMA }}= & -0.144+4.95 \square \mathrm{V}^{-1}-13.37 \square \mathrm{V}^{-2}+15.03 \square \mathrm{V}^{-3} \\
& -5.45 \square \mathrm{V}^{-4} \\
\mathrm{~B} / \mathrm{B}_{\text {SMA }}= & 0.5545+0.45 \square \mathrm{V}^{-1}
\end{aligned}
$$

とした。ただし，

$$
\begin{aligned}
& V= 1 /\{(1.0-0.16[\mathrm{C}]) \square(1.05-0.05[\mathrm{Si}]) \square \\
&(1.04-0.016[\mathrm{Mn}]) \square(1.0-0.5[\mathrm{P}]) \square(1.0+1.9[\mathrm{~S}]) \square \\
&(1.0-0.10[\mathrm{Cu}]) \square(1.0-0.12[\mathrm{Ni}]) \square(1.0-0.3[\mathrm{M} 0]) \square \\
&(1.0-1.7[\mathrm{Ti}])\} \\
& \text { ただし }, 0.9 \leqq \mathrm{~V} \leqq 2.5
\end{aligned}
$$

(4)〜 (6) 式により現在では, 種々の合金成分が添加さ れた耐候性鋼の腐食量の予測が可能となってきている．

\section{3. 実 験 方 法}

\section{1 暴露試験}

\subsection{1 供 試 材}

暴露試験および腐食試験に用いた供試材は, Table 1 に 示すニッケル系高耐候性鋼 2 種とJIS-SM A である .

\subsection{2 暴 露 地}

暴露試験場所を Table 2 に示す，暴露試験は，実構造 物上, 厳しい腐食環境となる雨による洗い流しのない環 境を模擬し覆いを付けて実施した，表中の飛来塩分量は JIS Z 2382 に基づくガーゼ法により計測した 1年間の平 均値を用いた . 長期間継続して測定されている地点では， 実際の暴露期間の平均值を用いた .なお, 解析にあたっ て独自の暴露試験結果以外に, 先に示した三者共研の 9 年目までの解析結果 ${ }^{10)}$ を適宜用いた .

\section{2 再現腐食試験}

温度, 湿度, 塩分といった環境因子の腐食への影響は， 暴露試験結果からでは, 明瞭に得られないので, 実験室 内で温度, 湿度, 塩分を変化させた乾湿繰り返し試験を 行って調査した。装置には, ADVANTEC 製 AGX-325を 用いた。

乾湿繰り返しのサイクルは，1日の気候变化を想定し， $24 \mathrm{~h}$ 周期で, 次の 5 条件で行った . 乾湿の移行時間は 1 $\mathrm{h}$ であり，これは $12 \mathrm{~h}$ の中に含まれる.塩分はマイクロ ピペットを用いて $\mathrm{NaCl}$ 水溶液を滴下して付着させた . 滴下量は $40 \mu \mathrm{L} / \mathrm{cm}^{2}$ とし，水溶液濃度により付着塩分量 を制御した・試験条件は，

Table 1 Chemical composition of employed steel.

\begin{tabular}{c|c|c|c|c|c|c|c|c|c}
\hline & \multicolumn{10}{|c}{ Chemical composition } \\
\cline { 2 - 11 } & $\mathrm{C}$ & $\mathrm{Si}$ & $\mathrm{Mn}$ & $\mathrm{P}$ & $\mathrm{S}$ & $\mathrm{Cu}$ & $\mathrm{Ni}$ & $\mathrm{Cr}$ & $\mathrm{Mo}$ \\
\hline \hline $1.5 \mathrm{Ni}-0.3 \mathrm{M}$ Mteel & 0.07 & 0.31 & 0.68 & 0.032 & 0.002 & - & 1.44 & - & 0.32 \\
\hline $0.02 \mathrm{C}-2.5 \mathrm{Ni}$ steel & 0.02 & 0.29 & 0.92 & 0.006 & 0.005 & 0.37 & 2.68 & - & - \\
\hline JIS-SMA & 0.09 & 0.25 & 1.05 & 0.010 & 0.005 & 0.33 & 0.20 & 0.53 & 0.03 \\
\hline
\end{tabular}


Table 2 Exposure site.

\begin{tabular}{c|c|c|c|c|c|c}
\hline \multirow{2}{*}{ Place Name } & \multirow{2}{*}{ Division } & $\begin{array}{c}\text { Air-borne } \\
\text { salinity }\end{array}$ & $\begin{array}{c}\text { Distance } \\
\text { from coast }\end{array}$ & \multicolumn{3}{|c}{ Employed steel } \\
\cline { 3 - 7 } & mdd & $\mathrm{km}$ & JIS-SMA & $1.5 \mathrm{Ni}-0.3 \mathrm{Mo}$ & $0.02 \mathrm{C}-2.5 \mathrm{Ni}$ \\
\hline \hline Kouchi A & Mountainside & 0.06 & 25 & 0 & 0 & \\
\hline Iwate & Pacific coast & 0.06 & 1 & 0 & 0 & 0 \\
\hline Kouchi B & Mountainside & 0.07 & 25 & 0 & 0 & \\
\hline Tottori & $\begin{array}{c}\text { Japan Sea } \\
\text { coast (South) }\end{array}$ & 0.12 & 0.55 & 0 & & 0 \\
\hline Kurashiki & Setonaikai & 0.22 & 0.01 & 0 & & 0 \\
\hline Ehime A & Pacific coast & 0.26 & 0.1 & 0 & 0 & \\
\hline Ehime B & Pacific coast & 0.26 & 0.1 & 0 & 0 & \\
\hline Tsu & Pacific coast & 0.30 & 1.6 & 0 & 0 & \\
\hline Choshi & Pacific coast & 0.38 & 4 & 0 & 0 & \\
\hline Miyakojima & Okinawa & 0.47 & 1 & 0 & 0 & 0 \\
\hline Oihama & Pacific coast & 0.60 & 0.02 & 0 & & 0 \\
\hline Gushikawa & Okinawa & 1.25 & 0.03 & 0 & 0 & 0 \\
\hline Ishikawa & $\begin{array}{c}\text { Japan Sea } \\
\text { coast (Nouth) }\end{array}$ & 1.30 & 0.08 & 0 & 0 & 0 \\
\hline
\end{tabular}
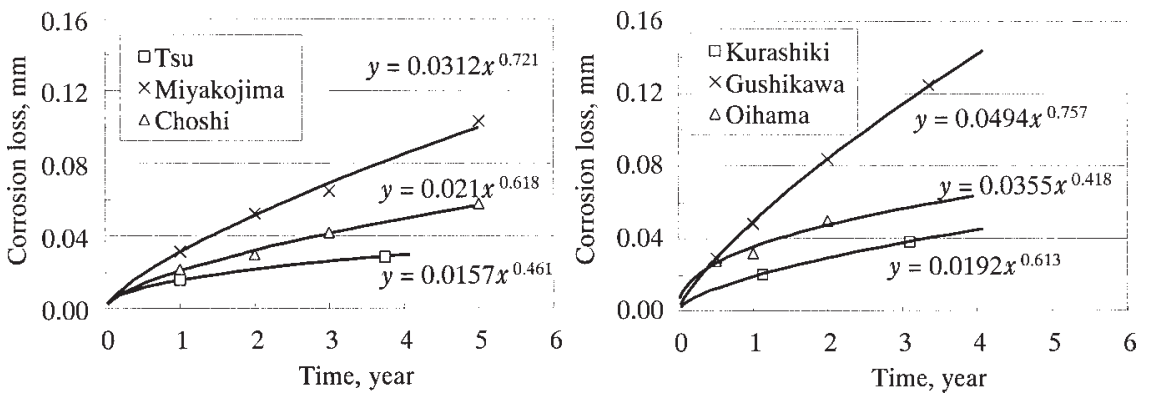

Fig. 1 Result of exposure tests under cover (left ; $1.5 \mathrm{Ni}-0.3 \mathrm{M}$ o steel, right; $0.02 \mathrm{C}-2.5 \mathrm{~N} \mathrm{i}$ steel).

(1) $13^{\circ} \mathrm{C} / 95 \% \times 12 \mathrm{~h}-20^{\circ} \mathrm{C} / 65 \% \times 12 \mathrm{~h}$

(2) $20^{\circ} \mathrm{C} / 95 \% \times 12 \mathrm{~h}-27^{\circ} \mathrm{C} / 65 \% \times 12 \mathrm{~h}$

(3) $25^{\circ} \mathrm{C} / 95 \% \times 12 \mathrm{~h}-32^{\circ} \mathrm{C} / 65 \% \times 12 \mathrm{~h}$

(4) $20^{\circ} \mathrm{C} / 95 \% \times 12 \mathrm{~h}-35^{\circ} \mathrm{C} / 40 \% \times 12 \mathrm{~h}$

(5) $25^{\circ} \mathrm{C} / 95 \% \times 12 \mathrm{~h}-40^{\circ} \mathrm{C} / 40 \% \times 12 \mathrm{~h}$

とし，試験期間は最長 52 週間まで行った .

\section{4. 実 験 結 果}

\section{1 暴露試験結果}

ニッケル系高耐候性鋼の暴露試験結果の一例を Fig. 1 に示す. 図中に示した式は, 回帰に基づき (1) 式の係数 A，B を決定したものである.飛来塩分の高い環境ほど腐 食量が大きく，係数 B が大きくなることがわかる .

回帰によって得られた係数 $A, B$ を用いて 100 年後の腐 食量を推定した．以降で腐食量は片面板厚減少量として 表す. 推定した結果と各暴露地の飛来塩分量との関係を Fig.2 に示す.Fig.2 中に示す直線の通り，各鋼種とも腐 食量は塩分量に対し屈曲点を持つことがわかる．屈曲点 より右側の領域では, さびの保護性が低下し, B の值が 1 に近くなったものと考えられる．ただし，図はばらつ きも大きいので, 実構造物への鋼材の適用判断にあたつ ては, 塩分のみを指標とするのではなく架設環境の温度， 湿度といった他の環境因子を考慮した上, 総合的に判断 することが必要である．なお三者共研のJIS-SM A の腐食
量と飛来塩分の関係に比べ, 本実 験は高塩分方向にシフトしてい る.三者共研では飛来塩分を実橋 の桁下内部で測定していたのに対 し，本試験では風通しの良い環境 で測定している.このため測定さ れた飛来塩分が三者共研当時より も高かったものと考えられる。

\section{2 再現腐食試験結果}

再現腐食試験におけるJIS-SM A の付着塩分量ごとの腐食量の経時 変化を Fig. 3 に示す.（a）は 0.4 mdd，(b) は $0.2 \mathrm{mdd}$ 人工海塩を付 与したものである.(1)式のB の 值は 0.5〜0.73 の値を示した . 付 与した塩分の少ない方が，(1) 式 のいずれの鋼種も B の值は小さ い.これは本試験では, 鋼の初期 の耐食性すなわち A の値におよぼ す効果のみならず, さびによる保 護効果の鋼種の影響が再現されて いることを示すものである .

Fig. 4 には再現腐食試験から求 めた塩分依存性を示す.光の結果， 傾き $\gamma$ はいずれもほぼ一定の 0.9 を示した . 温度と腐食量の関係を Fig. 5 に示す . 2 種のニッケル系 高耐候性鋼の傾きは同等であった が , JIS-SMA は傾きが異なった .

5. 考察

以上で得られた暴露データ，ならびにラボ実験の温度， 湿度の影響を用いて JIS-SM A , 2 種類のニッケル系高耐 候性鋼についておのおのの腐食量を直接回帰する式を作 成し，従来の予測方法と比較，考察を試みた。

\section{1 係数 $A$ の考え方}

係数 $\mathrm{A}$ は， $\mathrm{X}=1$ とすると，初年度腐食量である．す なわち, さびによる保護効果があまりない状態における



Fig. 2 Results of estimated corrosion loss of $\mathrm{Ni}$-added high corrosion resistant weathering steels after 100 years. 
年間腐食量であり，同一鋼材であ れば環境が左右する．腐食量は電 気化学反応であり, 原理的には反 応速度式を時間積分していくこと により求めることができるが, 実 際の大気腐食の現象は時々刻々変 化するため, 実際の計算をするこ とはできない．また任意の場所， 時間変化における速度定数やパラ メータを設定することは不可能で ある。したがって, 腐食におよぼ す主要環境因子を抽出し, 暴露試
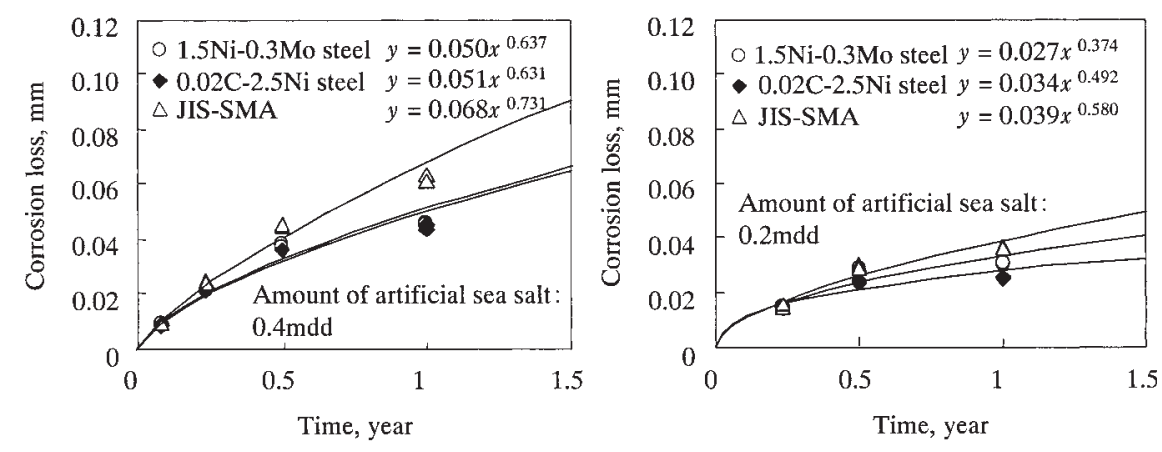

Fig. 3 Result of accelerated corrosion tests. 験結果との相関を求めた．著者ら は，2 章で説明した従来の予測方法を踏まえ，(2)式同樣 に温度係数, 濡れ時間, 促進係数を構成要素とし, $\mathrm{A}=\mathrm{k}(\alpha \square \mathrm{T}+\beta) \square \mathrm{TOW} \square \mathrm{C} \gamma$

$C$ : 飛来塩分 $\left(\mathrm{mg} / \mathrm{dm}^{2} / \mathrm{day}\right), \mathrm{TOW}$ : 濡れ時間 $(\mathrm{h}), \mathrm{T}$ : 気温 $\left({ }^{\circ} \mathrm{C}\right), \mathrm{k}$ : 定数, $\alpha, \beta, \gamma$ は鋼種に依存する係数とし た.

各構成要素を説明する.

・濡れ時間 (TOW)

濡れ時間は, 腐食反応が生じている時間であり, 腐食 量と直接比例すると考えられる. 実際に計算する際の数 值には, 年間平均気温, 年間平均湿度との相関から求め ることのできる Kucera の式12) による年間濡れ時間を用 いる

$$
\delta_{\mathrm{T}}=1\left(\mathrm{~T}>0^{\circ} \mathrm{C}\right) \text { or } 0
$$

$\delta_{\mathrm{RH}}=1(\mathrm{RH}>80 \%)$ or 0

$\mathrm{TOW} f \delta \mathrm{T} \times \delta \mathrm{RH} d \mathrm{t}$

$$
\begin{aligned}
= & 8766 \times \mathrm{P}\left(\mathrm{T}>0^{\circ} \mathrm{C}\right) \times \mathrm{P}(\mathrm{RH}>80 \%) \\
= & 8766 \times \mathrm{N}(\mathrm{T} ; 0 ; 9.96) \\
& \times \beta(\mathrm{RH} / 100 ; 4.67 ; 1.78)
\end{aligned}
$$

・温度関数 $(\alpha \cdot \mathrm{T}+\beta)$

反応は, 温度が高いほど促進されるが, 実際の対象と なる平均気温の範囲は比較的狭いことから，直線近似と した . 実際に計算する際の数値には, 年間平均気温を用 いて計算する． $\beta$ は $\mathrm{T}=0^{\circ} \mathrm{C}$ 近くでの A の值を示す .

- 促進係数 $(\mathrm{C} \gamma)$

上述した独自の暴露試験結果に基づき，飛来塩分が主 要な促進因子であるとしている土研の考え方を取り込ん だ.最近は, 国内の工業地帯では硫黄酸化物量が低下し， 他の臨海地域と区別する必要がなくなっていることか $ら^{10)}$, 本予測技術では, 硫黄酸化物の影響は取り込んで いない.

\section{2 係数 $B$ の考え方}

係数 B は, 経年で生じたさびの持つ保護効果の指標で ある.Fig. 6 に示すとおり，三者共研に見られる実際の B は 0.6〜1 程度を示す. 同一鋼材であれば, さびの構造 は環境によって決まると考え, 上述した環境指標である A の関数として表した . 三者共研から 3 次式で回帰を行 い, JIS-SM A における A と B の関係式 (9) を得た .

$$
\begin{aligned}
A<0.083 \text { のとき } B= & -4611.3 A^{3}+769.19 A^{2} \\
& -32.421 A+1.0109
\end{aligned}
$$

$0.083 \leqq A$ のとき $B=1$

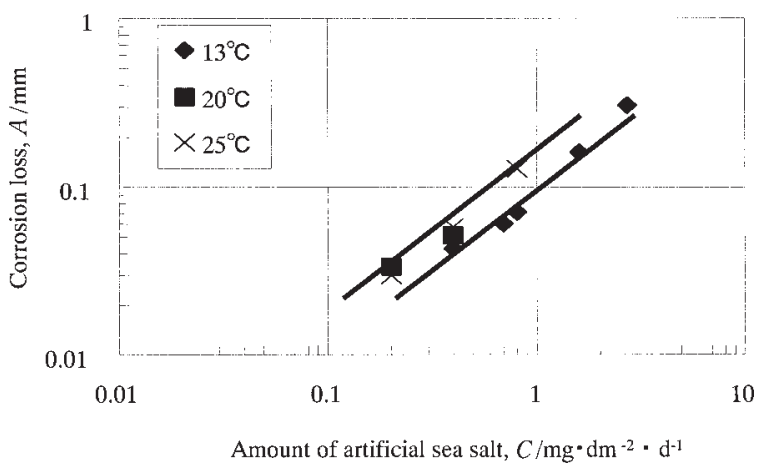

Fig. 4 Relationships between corrosion loss (A) and amount of artificial sea salt on $1.5 \mathrm{Ni}-0.3 \mathrm{M}$ o steel.

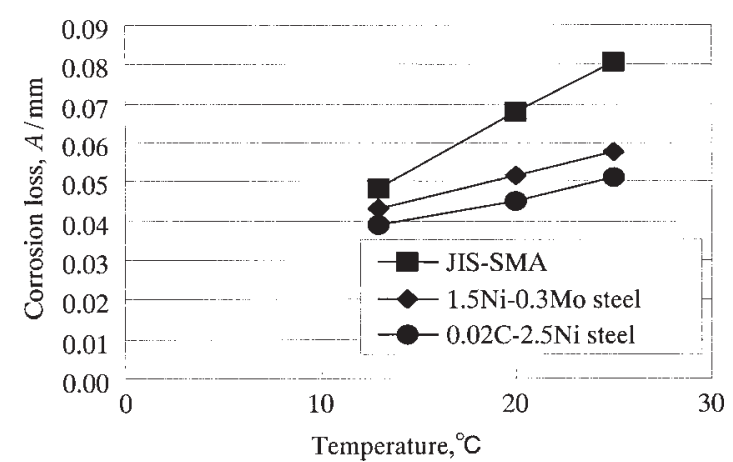

Fig. 5 Relationships between corrosion loss (A) and average temperature.

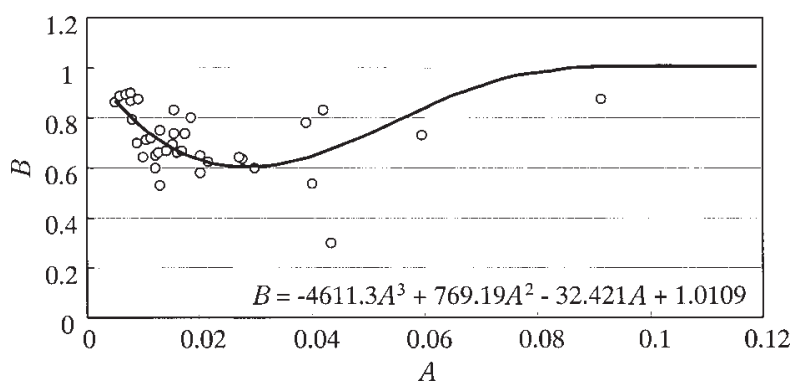

Fig. 6 Relationship between A and B on equation (1) of JIS-SM A.

\section{2 .1 直線則 $(B=1)$}

耐候性鋼の腐食量の経時変化が直線則に従うのは以下 の場合が考えられる .

1）さびの生成と脱離（風化）が釣合い, 見かけ上さ 
びの厚さ，組成が一定の状態

・長期経過後の平衡成立後

- 腐食環境が非常に緩やかで薄い皮膜

2）さびの保護性がない状態

・腐食環境が厳しく, 割れ, 層状剥離が頻繁に生じる など，さびの保護性がほとんど働かないとき

・さびが存在しない表面状態, すなわち極初期の状態

これらは，耐候性鋼に形成されるさびでは必ずしも明 確にはなっていない．

\section{2 .2 放物線則 $(B=0.5)$}

放物線則は, 皮膜成長が物質移動によってのみ支配さ れる状態で現れる.放物線則がよく適用される高温腐食 のスケールは, 素反応に関与する直接物質であるイオン (Fe)，電子の移動が律速であると仮定される ${ }^{13)}$. 一方， 耐候性鋼の腐食反応を律速する物質移動は, 酸素といっ た直接反応に関与する物質の移動ではなく，水の浸透， あるいは塩化物イオンといった反応環境を形成する間接 物質の移動が律速となっているものと考えられる . 実環 境で構成される耐候性鋼のさびの場合，Fig. 6 ならび (9) 式により， $A=0.03$ 程度で極小かつ最小のとき， $B=0.6$ 程度の值であり，B $=0.5$ までは低下しない .これは，さ びの層が不均一あるいは不完全であり，完全な物質移動 律速に従わないことに起因すると考えられる .さらに $A \geqq 0.03$ の領域では, さびに生じる割れなどによって保 護性が失われはじめ, 割れの発生確率により左右される 遷移過程を経て，しだいに直線則に近くなる。

\section{3 係数について}

Fig. 2 に示した塩分に対して腐食量の予測値が屈曲す る現象は，三者共研においても認められている．塩分の 係数 $\gamma$ は，4.2 に示したとおり塩分を変化させた再現腐 食試験結果を, 鋼種ごとに重回帰して決定した . 同樣に 温度係数 $\alpha, \beta$ は, 温度を変化させた再現腐食試験結果を， 鋼種ごとに重回帰して決定した .

また，(7)式における k の值は , JIS-SM A に関しては三 者共研の $\mathrm{A}$ を用いて決定した $\alpha, \beta, \gamma$ ならびに暴露地の 温度, 湿度を用いて計算した $\mathrm{A}^{\prime}=(\alpha \square \mathrm{T}+\beta)$ 口TOWםC $\gamma$ の 值と実際の腐食量をFig. 7 のように比をとり算出した . ここでkは

$$
k=A / A
$$

である

以上より，(7) 式の各係数は Table 3 のとおり決定した .

\section{4 予測結果の検証}

\subsubsection{JIS-SMA}

本結果に基づいて得られたJIS-SM A の A と B の関係 式に基づいて, 三者共研の 9 年目の暴露試験結果を予測 し，飛来塩分のみ考慮した（3）式の予測結果と比較した． Fig. 8 に示すとおり，本予測結果は，(3)式とくらべ，特 に腐食量の大きい領域で予測精度が向上することがわか る .これは $A=0.03$ の大小で, 異なる係数を設定したこ とによるものである

（1）式ならびに上記で設定してきた A， B を用いて求め られる腐食量の予測結果は, 年数 $X$ に応じた $Y$ の曲線で 示される.したがって, 基準とする長期腐食量（例えば 100 年で $0.5 \mathrm{~mm}$ ) を満たすか満たさないかの判断しかな
く，弚の予測値がどれだけの確率を持って示されている か不明である. 乥こで, 100 年後の予測値と回帰值の比 (10)式を指標として，暴露試験の 100 年後の R の正規確
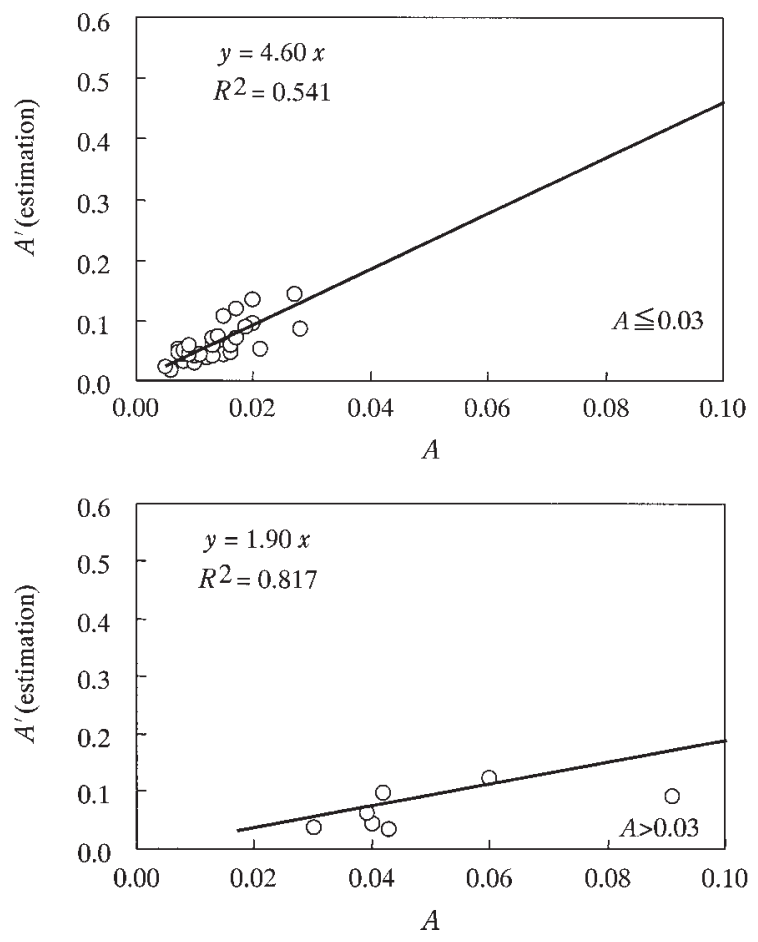

Fig. 7 Correlation between $A$ and $A$ :

Table 3 Coefficient of $\alpha, \beta, \gamma, \mathrm{k}$ on equation (7)

\begin{tabular}{c|c|c|c|c}
\multicolumn{1}{l|}{$A \leqq 0.03$} & $k$ & $\alpha$ & $\beta$ & $\gamma$ \\
\hline \hline $1.5 \mathrm{Ni}-0.3 \mathrm{Mo}$ steel & $4.0 \times 10^{4}$ & 0.02 & 0.13 & \\
\cline { 1 - 3 } $0.02 \mathrm{C}-2.5 \mathrm{Ni}$ steel & $4.0 \times 10^{4}$ & 0.02 & 0.05 & \multirow{2}{*}{0.49} \\
\cline { 1 - 3 } SMA & $4.0 \times 10^{4}$ & 0.02 & 0.54 & \\
\hline
\end{tabular}

\begin{tabular}{|c|c|c|c|c|}
\hline & $k$ & $\alpha$ & $\beta$ & $r$ \\
\hline $1.5 \mathrm{Ni}-0.3 \mathrm{Mo}$ steel & $1.7 \times 10^{4}$ & 0.01 & 0.08 & \multirow{3}{*}{0.90} \\
\hline $0.02 \mathrm{C}-2.5 \mathrm{Ni}$ steel & $1.7 \times 10^{4}$ & 0.01 & 0.03 & \\
\hline SMA & $1.7 \times 10^{4}$ & 0.02 & 0.55 & \\
\hline
\end{tabular}

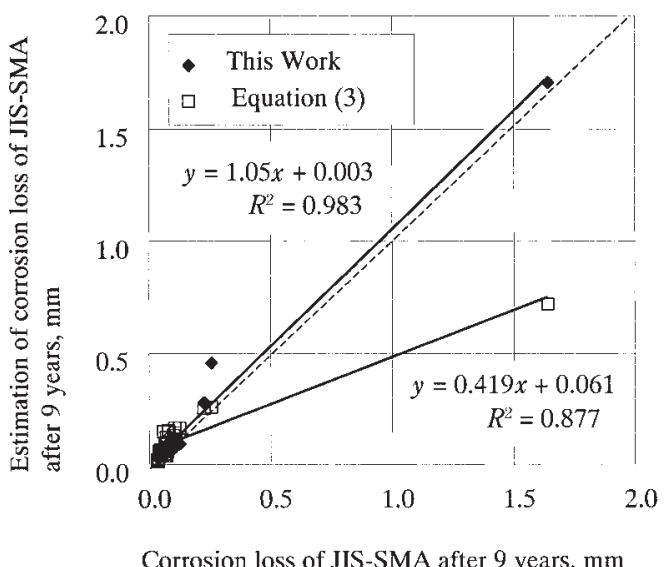

Fig. 8 Correlation between corrosion loss and estimated value of JIS-SM A. 


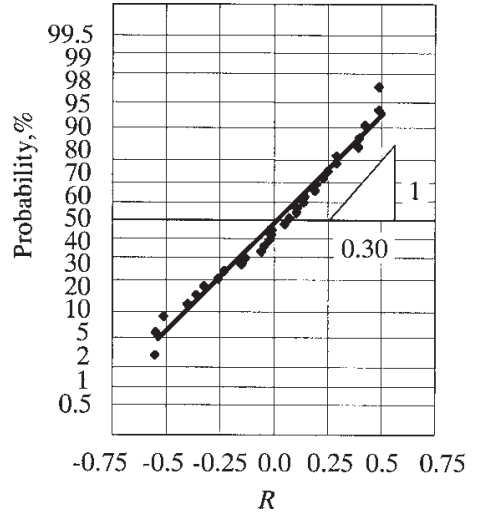

Fig. 9 Plots of R-value of selected 32 locations.

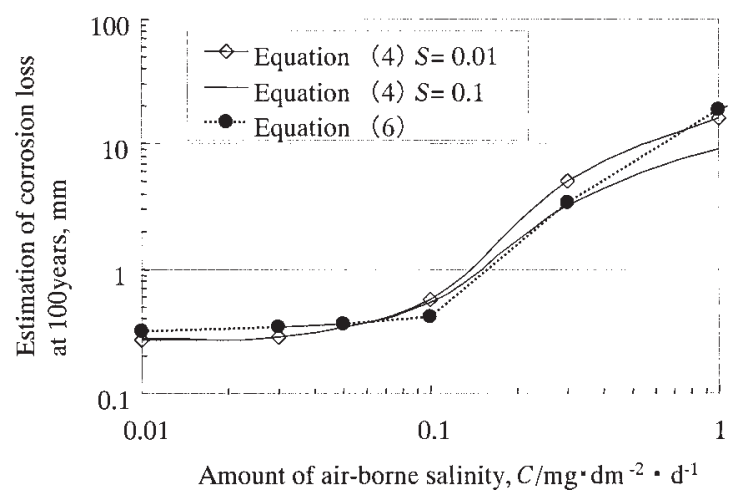

Fig. 10 Calculated corrosion loss of JIS-SM A derived from equation (7), compared with equation (4).

率プロットをFig. 9 に示す .

$R=($ 回帰値 - 本予測值 $) /$ 本予測值

周囲の環境が変化したとの記述がある地点, $\mathrm{B}$ が 1.1 を 超える点を除外した 32 橋の分布は, 良い直線関係が認 められ正規分布に従うことを示し， $\sigma=0.30$ が得られた .

次に（4)〜 (6) 式に基づく予測結果との検証を行った . Fig. 10 はJIS-SM A に関して, 新潟における温湿度の平年 値を用いて計算したものと，よく一致した .

\subsection{2 ニッケル系高耐候性鋼}

以上に基づいて (7)，(9)式ならびに Table 3 より得た二 ッケル系高耐候性鋼の予測結果を Fig. 11 に示す．また， Fig. 11 にはJIS-SMAのAに の)，(6)式に示した V 值を用 いて計算した予測結果を併せて示す．この結果は, Fig. 2 に示したニッケル系高耐候性鋼の暴露試験の回帰結果と はよく一致している.だたし，腐食量が増大する飛来塩 分量は, 本予測の結果では, $0.4 \mathrm{mdd}$ であるのに対し, $\mathrm{V}$ 値を用いた場合は $0.2 \mathrm{mdd}$ 程度と $\mathrm{V}$ 值による予測結果の

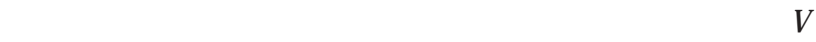
值の係数は, 暴露試験データがなか つた時期に設定されたものであるこ となどを含め, 今後 , 種々の暴露試 験データが得られることにより，さ らに詳細に検証されていくものと思 われる .

\section{5 降雨の影響}

上述した暴露試験ならびに再現腐

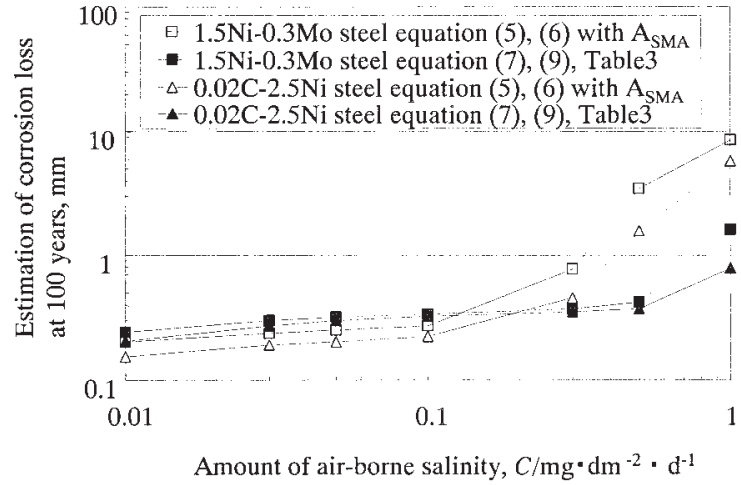

Fig. 11 Calculated corrosion loss of $\mathrm{Ni}$-added high corrosion resistant weathering steels after 100 years derived from equation (7) compared with derived $A_{S M A}$ and $V$-value

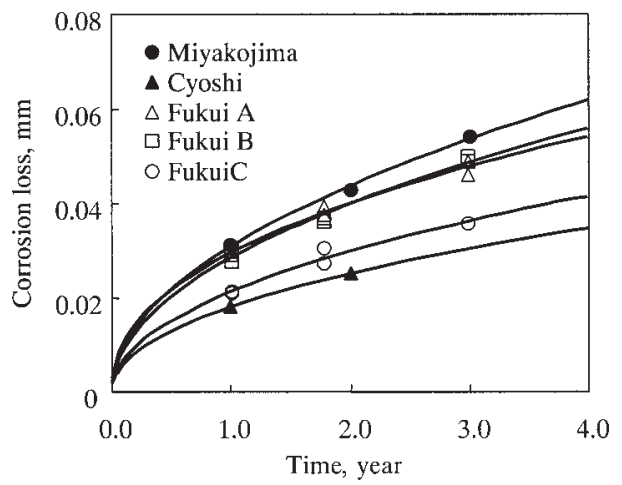

Fig. 12 Result of exposure test of $1.5 \mathrm{Ni}-0.3 \mathrm{M}$ o steel without cover.

食試験は，雨による洗い流しのない環境を模擬し，覆い 付きで実施したものであった . 洗い流しの効果を把握す るために, Table 1 の供試材のうち，1.5Ni-0.3M o 鋼につ いて, 宮古島, 銚子, ならびに福井県 3 か所の海岸近傍 計 5 か所で屋外の暴露試験を行った . 弚の結果を Fig. 12 に，また回帰係数 A，B を Table 4 に示す. 洗い流しのあ る環境では, 飛来塩分量が $0.5 \mathrm{mdd}$ 以上であっても，B は 5.2 で述べた放物線則に近い 0.5 程度の值を示してお り，100 年の腐食量予測值は $0.31 \mathrm{~mm}$ 以下となった .こ れは, 降雨のある環境では, 均一で保護効果が高いさび が生成しているためと推定される。

\section{6 表面処理の効果}

耐候性鋼の表面には初期の流れさび抑制，初期外観を 保つ目的で，さび安定化補助処理を施す場合がある。さ び安定化補助処理は，ある期間腐食環境を遮断すること で，腐食の進行を抑制する機能，および光の後の処理皮

Table 4 Coefficient of $Y=A X^{B}$ of exposure test of $1.5 \mathrm{Ni}-0.3 \mathrm{M}$ o steel without cover.

\begin{tabular}{c|c|c|c|c|c}
\hline & Miyakojima & Cyoshi & Fukui A & Fukui B & Fukui C \\
\hline \hline $\begin{array}{c}\text { Amount of air-borne } \\
\text { salinity(mdd) }\end{array}$ & 0.54 & 0.23 & 1.30 & 0.59 & 0.59 \\
\hline$A$ & 0.031 & 0.018 & 0.029 & 0.028 & 0.021 \\
\hline$B$ & 0.50 & 0.47 & 0.45 & 0.49 & 0.49 \\
\hline $\begin{array}{c}\text { Estimated corrosion loss } \\
\text { after 100 years }\end{array}$ & 0.31 & 0.16 & 0.23 & 0.27 & 0.20 \\
\hline
\end{tabular}






Fig. 13 Effect on surface treatment of weathering steel for corrosion.

膜の劣化に伴い皮膜下で保護性さびの形成を補助する機

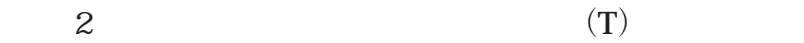
をプライマー $(\mathrm{P})$ 機能と称する7) . しかし長期間経過の 後には処理皮膜が消失し, 弚の後は保護性さびが形成さ れた無塗装の耐候性鋼と同樣に腐食が進行する . 腐食量 の予測には本処理の影響を考慮しなければならない．

Fig. 13 に無塗装耐候性鋼が(1)式に従って腐食し 100 年で $0.5 \mathrm{~mm}$ 腐食する環境において, さび安定化補助処 理を施し, トップコートの効果を 15 年, 光の後のプラ イマーの効果を 10 年としたときの腐食抑制効果の概念 図を示す．トップコート，プライマーの効果の持続期間 については処理斉の種類, 環境によっても変化し，また プライマーにより皮膜下に形成された保護性さびの性質 によって，処理皮膜が消失した後の腐食速度が変化する と考えられるが, 現段階では処理皮膜消失後の腐食量に 関しては十分な暴露データが無いのが実情である。従っ て，ここでは定量的な検討はできないが，耐候性鋼が無 塗装で使用可能な領域では腐食量を低減する効果はある ことがわかる.今後，長期暴露材解析に基づく定量的な 解析結果を期待したい。

$$
\text { 6. 結言 }
$$

2 種類のニッケル系高耐候性鋼について，覆い付き暴 露試験を全国で実施し，3〜5 年経過した試験片を解析し
た結果，以下を得た。

1）暴露試験と温度，湿度，塩分量を調節した実験室 での再現腐食試験の結果を加え, 各鋼種の腐食量予測式 を作成した，弚の結果，JIS-SMA に関しては，過去の結 果とよく一致した .ニッケル系高耐候性鋼に関しては， これまで提案されてきた耐候性合金指標 $\mathrm{V}$ 值に基づく予 測結果より飛来塩分に対して高い耐食性を示した。

2）上記以外に，耐候性鋼の適用に関し，洗い流しの ある環境に暴露した場合, 海岸近傍の $0.5 \mathrm{mdd}$ を越える 環境において良好な耐食性を示すことがわかった .さび 安定化補助処理を適用した場合, 無塗装で適用可能な環 境では腐食量を低減する効果が考えられる。

\section{参 考 文 献}

1) Public Works Research Institute, Kozai Club, Japan Bridge Association : Report on Application of Weathering Steel for B ridge (XV), (1992).

2) A. Usami, Y. Tomita, H. Kihira, T. Tsuzuki and K. Tanabe, Proc. JSCE M aterials and Environments 1998, p.65, JSCE (1998).

3) C. M iki, A. Ichikawa, M. Ukai, M. Takemura, T. Nakayama and H. Kihira, J. Structural M echanics and Earthquake Engineering, No.738/ I-64, 271 (2003).

4) H.Kihira, Proc. $145^{\text {th }}$ Symposium, p.43, JSCE (2004).

5) H. Kihira, K. Tanabe, T. Kusunoki, H. Takezawa, H. Yasunami, M. Tanaka, K. M atsuoka and Y. Harada, J. Structural M echanics and Earthquake Engineering, No.780/-70, 71 (2005)

6) I. Kage, K. Shiotani, M. Takemura, T. Komori and K. Kyono, Proc. 51th Jpn. Conf. M aterials and Environments, p.81, JSCE (2004).

7) K. Horikawa, S. Takiguchi, Y. Ishizu and M. Kanasashi, B oshoku-Gijutsu (presently Zairyo-to-Kankyo), 16, 153 (1967).

8) G. Nakamura et al., J. M et. Finish. Soc. Jpn. 33, 77 (1982).

9) Japan Institute of Construction Engineering, "Improvement in Durability of Steel Construction", Gihodo-shuppan, p.86 (1986)

10) Public Works Research Institute, Kozai Club, Japan Bridge Association: Report on Application of Weathering Steel for Bridge (XVIII), (1993)

11) Report on Standardization of New Generation in Fiscal 1996 J apan Weathering Test Center (1997).

12) V. Kucera, J. Tidblad and A. M ikhailov, ISO/ TC156/ WG4N314, Annex A (1999).

13) T. Narita and K. Nishida, "Kinzoku no kouonsanka nyumon", M aruzen (1988).

( $M$ anuscript received J anuary 24, 2006; in final form February 15, 2006)

耐候性鋼材は構造物に適用する際，環境に適合するかどうかの判断が重要となる．著者らは，従来から 用いられてきた耐候性鋼 (JIS-SM A) ならびにニッケル系高耐候性鋼について全国各地で行ってきた暴露試 験の結果を元に , 環境因子と長期の腐食量の関係を表す式を構築してきた .

本論文では，最初にこれまで提案されてきた耐候性鋼に関する種々の腐食予測方法を整理し，実施した 暴露試験の結果に基づいて, 飛来塩分を代表とする国内環境に対する特性変化を明らかにした .これらの 鋼材について一部実験室で行った腐食試験結果を加え，腐食予測曲線を立案した。关の結果，耐候性鋼は， 従来の知見とよい一致を示したが，ニッケル系高耐候性鋼は，これまで提案されてきた耐候性合金指標 $\mathrm{V}$ 值に基づく予測結果より塩分に対して高い耐食性を示す可能性があることを示した .さらに，降雨を受け る構造とすることやさび安定化補助処理を施すことにより，長期間の腐食量を抑制させることができるこ とを示す

$$
\text { キーワード大気腐食, 而候性鋼, 腐食量予測, 鋼橋, 温度, 湿度, 飛来塩分, 暴露試験 }
$$

